\title{
Nature's Sonic Order on the Western Front
}

L'ordre sonore de la nature sur le front de l'Ouest

\section{Michael Guida}

\section{(2) OpenEdition}

\section{Journals}

Electronic version

URL: http://journals.openedition.org/transposition/4770

DOI: $10.4000 /$ transposition.4770

ISSN: $2110-6134$

\section{Publisher}

CRAL - Centre de recherche sur les arts et le langage

\section{Electronic reference}

Michael Guida, «Nature's Sonic Order on the Western Front », Transposition [Online], Hors-série 2 | 2020, Online since 15 March 2020, connection on 16 April 2020. URL : http://journals.openedition.org/ transposition/4770 ; DOI : https://doi.org/10.4000/transposition.4770

This text was automatically generated on 16 April 2020.

\section{(c) (†) (อ)}

La revue Transposition est mise à disposition selon les termes de la Licence Creative Commons Attribution - Partage dans les Mêmes Conditions 4.0 International. 


\title{
Nature's Sonic Order on the Western Front
}

\author{
L'ordre sonore de la nature sur le front de l'Ouest
}

\author{
Michael Guida
}

1 The sound of human conflict can only be made sense of in relation to the surrounding reference sounds of the natural world. It is in the extreme conditions of wartime that the context of the natural world takes on renewed sensory power. Here I suggest we pay attention to nature's sounds and their reception to better understand the ways in which men experienced and endured the fighting on the Western Front in the First World War. To survive in that place it was necessary to listen to the surrounding environment for sounds of danger, safety and relief. There was much more to hear than battle noise in the trenches and I argue that under conditions that were barely tolerable the sounds of the natural world needed to be heard and, when they were, they were assigned special meaning. The soldier's writing during and after the war that I examine makes clear that the disorder of trench experience could in part be managed or even reversed when the sounds of nature were brought to auditory attention.

2 There is no doubt that technological battle noise was overwhelming to combatants on both sides of the line. ${ }^{1}$ However, over time the idea of the monstrous noise of the guns has saturated post-war narratives with its symbolism of a new scale of technological violence and combined with the psychological phenomenon of "shell shock" has become a prism through which much of the cultural history of the 1914-18 has been viewed. ${ }^{2}$ Ford Madox Ford, who served in the Welch Regiment and lost his memory for three weeks when he was concussed by a shell explosion, wrote that the noise "said things of an intolerable intimacy". ${ }^{3}$ The noise got inside the body and into mind. Young German recruits exposed to the crash of artillery were left "green and throwing up", Erich Maria Remarque reported a decade after his combat experience in All Quiet on the Western Front. ${ }^{4}$ Memory was deeply impressed by the sound of shelling, Robert Graves telling five decades on of a noise that "never stopped for one moment - ever". ${ }^{5}$ Nevertheless, scholars must work beyond these kinds of accounts if trench experience and the techniques of emotional survival are to be better understood. 
3 Like so much war, the Western Front conflict was played out within nature - the field of battle was a trench network cut into hundreds of miles of landscape, recognised by British soldiers at least initially as pastoral and pleasantly evocative of home. Even the decimation of the French and Belgian countryside over the course of the war did not prevent it retaining certain rural potencies in the minds of those who were submerged there. Civilian soldiers from the suburbs or the city found themselves hard pressed to the rawness of the natural world. Combat experience had to be measured to some extent against this immediate natural environment. The deathly expanses of mud and tree stumps familiar from trench photography (which in fact supported a new ecosystem of owls, rats and corpses) were a reality for many in the front line, but soldiers cycled through the tiers of the trench system, resting in reserve trenches or behind the lines. In all of these places men encountered and wrote about the natural world, which seemed to carry on and even thrive. ${ }^{6}$ Men may have lived underground, in the "troglodyte world" of the trenches as Paul Fussell called it, with feet sucked by a terrible compost, trapped in "one huge grave", 8 but there was hope above this mess.

Soldiers' letters, diaries, memoirs and poems reveal that amid the chaos of war, and perhaps because of it, nature was heard to sound out. The songs of birds, the murmur of trees and the stillness of the cosmos were rich in meaning to men in peril. To perceive - or to imagine - such sounds within the tyranny of bombardment or the haunted silences that followed was not unusual. Paying attention to the sonic environment was a way to understand the status and safety of ones' surroundings, which could rarely be reliably gauged through vision. In the trench system "hearing became much more important than vision as an index of what was real and threatening", Eric Leed has argued. ${ }^{9}$ The "sonic-mindedness" of German troops that Yaron Jean has described came from auditory training to distinguish between different kinds of overhead ordnance. ${ }^{10}$ Airborne projectiles were named by British troops for their sonic character (Coal Boxes, Jack Johnsons, Whizz-Bangs), as the identification of alien sounds was the first part of avoiding danger. ${ }^{11}$ This kind of acute listening was a technique of survival that gave renewed significance to all sounds. Ford Madox Ford noticed that the texture of the landscape altered the sound of artillery fire and he wrote to his friend Joseph Conrad about it: "In woody country heavy artillery makes the most noise, because of the echoes... On dry down land the sound is much sharper; it hits you \& shakes you". ${ }^{12}$ This was not only literary sensitivity at work; sound-ranging techniques requiring this kind of knowledge were being developed by engineers to locate enemy artillery positions.

5 Finding ways to listen through and beyond the noise was necessary. There were other sounds to be heard, birdsong in particular. Some accounts give the impression that birdsong was pulled from the air despite the noise. Ford told a friend in a letter that amid the noise "the ear picks out the singing of innumerable larks". ${ }^{13}$ Such small but urgent sounds needed to be heard. The sound of the most ordinary birds like sparrows and starlings offset the "grime of battle". ${ }^{14}$ Of course there were lulls in the firing and into these spaces sounds of significance would find a place. Theodore Wilson wrote to his aunt in April 1916: "I'm writing in a trench not very far from the Germans and I've just heard the first cuckoo!"15 This incongruous report came from the tradition in England of being the first to identify the herald of spring. Wilson had managed to find a sense of homeliness and continuity in the trenches. 
6 The silence after a bombardment or at night-time presented an antithesis to the noise that could rarely be savoured. Agitated alertness persisted, ears straining for meaning. In a listening-post poking out into no-man's-land Frederick Harvey found himself afraid to move or whisper "waiting in wonder whether "twas the breeze moved in the grass, shaking the frozen flowers just then". ${ }^{16}$ In the darkness, the screams of wounded men in no-man's-land might be accompanied by the liquid notes of a nightingale. Reflecting on this dreadful juxtaposition, one soldier felt that the nightingale's song was "the only real thing which would remain when all the rest was long past and forgotten". ${ }^{17}$ More than any other, the nightingale's song was loaded with meaning and symbolism, but so were many encounters with nature's sounds that were known from home. Remarque's protagonist in All Quiet on the Western Front escaped his night-watch duty for a moment in a reverie in which he was back with his boyhood friends beneath a row of poplar trees where the wind sang. ${ }^{18}$ These memories felt "quiet" to him even if they were not when first experienced. Remarque called them "soundless apparitions" and they were accompanied by longing and melancholy more than hope. The trees that Edmund Blunden met in the darkness could be sinister broken figures or proud sentinels standing tall. Some provided companionship even if they were not very talkative. He wrote that one "sad guard of trees dripping with the dankness of autumn had nothing to say but sempiternal syllables". ${ }^{19}$ Difficult silences could be punctuated by private communication with nature, when speaking out loud was not possible.

7 These responses to an encounter with nature's sounds often suggest a search for order and rhythm in trench life. The sonic extremes of noise and silence were intolerable and demanded alternatives. Birdsong structured the unpredictability of trench-time, when sleep and circadian rhythms were dislocated, most notably my research has shown with the lark heard at day-break and the nightingale at night-time. To engage with these sounds was to find pattern and sense within the incoherence of trench existence. When the artillery officer and poet, Edward Thomas, recorded in his diary the sounds of birds together with his unit's shelling, it was as if the two gave shape and balance to a morning ritual that could continue indefinitely. "Up at 4.30. Blackbirds sing at battery at 5.45 - shooting at $6.30 " .{ }^{20}$ Without the birds, just the shooting would remain and the counter-weight to the pounding of guns would be gone.

8 There is a question about how much could actually be heard amid the cacophonies of shelling (although both the song and the roar may well have been accentuated in soldiers' accounts). If some of the sounds of nature recorded in primary sources were works of fantasy or the imagination, they were clearly needed and meaningful and therefore warrant attention. Though remembered and 'fictional' accounts are accused of perpetuating myths, I have found they are not very different to unpublished diaries kept by combatants during the war. ${ }^{21}$ Like others, I have drawn upon the writing of all ranks but the men who wrote were often of a middle-class literary mind. Were these men particularly sensitive to nature's sounds and its poetry? Perhaps so, but I tend to think that what they felt was common to many who did not have the chance to express themselves in writing. There is also a question of soldiers' writing giving expression to pastoral motifs, beloved of much writing of the period, rather than reality. Paul Fussell's literary analysis The Great War and Modern Memory saw "recourse to the pastoral" as an English mode of both "fully gauging the calamities of the Great War and imaginatively protecting oneself against them". ${ }^{22}$ However, I have worked with material that gives precedence to immediate lived experience rather than imaginative 
impressions. Indeed, I see soldiers' engagement with nature sounding out as evidence of living urgently in present tense, rather than reaching back for the comfort of tradition. To hear a bird meant you, and it, were alive and might continue to be. The responses to nature in soldiers' writing show a determined effort to make meaning and sense out of a sound world that seemed to deny such a possibility.

9 Soldiers drew towards them sounds that were explicitly not about the war because they offered refreshing meanings. Most written about was the vitality and energy of singing birds whose sound was known from home and signified to many patriotic defiance and resilience. The occupation of the air above the trenches by birdsong signified that sonic order and perhaps universal order had been reinstated. Birdsong rose free from the stasis and filth of the trenches and into the sky where it could purify the corrupted atmosphere. The punch of detonations, the cries of the wounded, the hiss of corpses could be cleansed with the notes of bird song, if only momentarily. Birdsong could disrupt the violence of explosion with familiar, chiming musicality. It could counter the excruciating weight of shelling with a lightness and freedom. The lark's overhead cascade turned eyes upwards towards the stillness of the cosmos. This connection to the peace and permanence of the heavens, to nature in its most perfect grandeur, was noticed by the troops on the ground. Robert Sterling in a letter to a friend admitted that he had been "longing for some link with the normal universe detached from the storm". He found in the "sightless song" of a lark "the very essence of the Normal and Unchangeable Universe carrying on unhindered...". ${ }^{23}$

\section{BIBLIOGRAPHY}

BLUNDEN Edmund, Undertones of War, London, Penguin, 2000 [1928].

BULL Michael, "Into the Sounds of War: Imagination, Media and Experience", GRIMSHAW-AAGAARD Mark, WALTHER-HANSEN Mads and KNAKKERGAARD Martin (eds.), The Oxford Handbook of Sound and Imagination, Oxford, Oxford University Press, 2019, p. 175-202.

FORD Ford Madox, No More Parades, Manchester, Carcanet, 2011 [1925].

FUSSELL Paul, The Great War and Modern Memory, New York, Oxford University Press, 2013 [1977].

GILLESPIE Alexander, Letters from Flanders, London, Smith and Elder, 1916.

GRAVES Robert, “The Great Years of Their Lives”, The Listener, 15 July 1971, p. 74.

HABECK Mary, “Technology in the First World War: The View From Below”, WINTER Jay, PARKER Geoffrey and HABECK Mary (eds.) The Great War and the Twentieth Century, New Haven, Yale University Press, 2006, pp. 99-131.

HARVEY Frederick, poem “A True Tale of the Listening Post”, NOAKES Vivien (ed.), Voices of Silence: The Alternative Book of First World War Poetry, Stroud, The History Press, 2006, pp. 90-91.

HOUSMAN Lawrence (ed.), War Letters of Fallen Englishmen, New York, EP Dutton, 1930. 
JEAN Yaron, "The Sonic Mindedness of the Great War: Viewing History through Auditory Lenses", FEIEREISEN Florence and MERLEY HILL Alexandra (eds.) Germany In the Loud Twentieth Century, New York, Oxford University Press, 2012, pp. 51-62.

LAFFIN John (ed.), Letters from the Front, 1914-18, London, JM Dent, 1973.

LEED Eric J, No Man's Land: Combat and Identity in World War I, Cambridge, Cambridge University Press, 1979.

LEWIS-STEMPEL John, Where the Poppies Blow: The British Soldier, Nature, the Great War, London, Weidenfeld \& Nicolson, 2016.

LUDWIG Richard M, Letters of Ford Madox Ford, Princeton, Princeton University Press, 1965.

NASH Paul, Outline. An Autobiography and Other Writings, London, Faber \& Faber, 1948.

REMARQUE Erich Maria, All Quiet on the Western Front, London, Vintage, 1996 [1929].

SAUNDERS Max, "Ford Madox Ford (1873-1939): Biography" (http://

www.fordmadoxfordsociety.org/fords-biography.html, accessed 20 December 2019).

THOMAs R George (ed.), Edward Thomas: Collected Poems, London, Faber \& Faber, 2004.

VANDEVELDE Tom, “'Are you Going to Mind the Noise?': Mapping the Soundscape of Parade's End”, CHANTLER Ashley and HAWKes Rob (eds.), Ford Madox Ford's Parade's End: The First World War, Culture, and Modernity, Amsterdam, Rodopi, 2014.

WINTER Jay, "Shell-Shock and the Cultural History of the Great War", Journal of Contemporary History, vol. 35, no. 1, 2000, pp. 7-11.

ZEEPVAT Charlotte (ed.), Before Action: William Noel Hodgson and the 9th Devons: A Story of the Great War, Barnsley, Pen \& Sword, 2015.

\section{NOTES}

1. For example, HABECK Mary, “Technology in the First World War: The View From Below”, wINTER Jay, PARKER Geoffrey and HABECK Mary (ed.) The Great War and the Twentieth Century, New Haven, Yale University Press, 2006, pp. 103-112.

2. WINTER Jay, "Shell-Shock and the Cultural History of the Great War", Journal of Contemporary History, vol. 35, no. 1, 2000,p p. 7-11.

3. SAUNDERS Max, "Ford Madox Ford (1873-1939): Biography" ( http:// www.fordmadoxfordsociety.org/fords-biography.html, accessed 20 December 2019). Quotation in FORD Ford Madox, No More Parades, Manchester, Carcanet, 2011 [1925], p. 11.

4. REMARQUE Erich Maria, All Quiet on the Western Front, London, Vintage, 1996 [1929], p. 76.

5. GRAVES Robert, "The Great Years of Their Lives”, The Listener, 15 July 1971, p. 74.

6. LEWIS-STEMPEL John, Where the Poppies Blow: The British Soldier, Nature, the Great War, London, Weidenfeld \& Nicolson, 2016.

7. FUSSELL Paul, The Great War and Modern Memory, New York, Oxford University Press, 2013 [1977], p. 39.

8. NASH Paul, Outline. An Autobiography and Other Writings, London, Faber \& Faber, 1948, p. 186.

9. LEED Eric J, No Man's Land: Combat and Identity in World War I, Cambridge, Cambridge University Press, 1979, p. 124. 
10. JEAN Yaron, "The Sonic Mindedness of the Great War: Viewing History through Auditory Lenses", FEIEREISEN Florence and MERLEY HILL Alexandra (eds.) Germany In the Loud Twentieth Century, New York, Oxford University Press, 2012, pp. 53-55.

11. WILLIAMS JS, letter, 3 October 1915, Letters from the Front, 1914-18, LAFFIN John (ed.), London, JM Dent, 1973, p. 58; BLUNDEN Edmund, Undertones of War, London, Penguin, 2000 (1928), pp. 38-39.

12. LUDWIG Richard M, Letters of Ford Madox Ford, Princeton, Princeton University Press, 1965, p. 73.

13. VANDEVELDE Tom, “'Are you Going to Mind the Noise?': Mapping the Soundscape of Parade's End", CHANTLER Ashley and HAWKes Rob (eds.), Ford Madox Ford's Parade's End: The First World War, Culture, and Modernity, Amsterdam, Rodopi, 2014, p. 59.

14. HodGson William, poem "Back to Rest", quoted in zEEPVAT Charlotte (ed.), Before Action: William Noel Hodgson and the 9th Devons: A Story of the Great War, Barnsley, Pen \& Sword, 2015, p. 130.

15. WILSON Theodore, letter to his aunt, 27 April 1916, HOUSMAN Lawrence (ed.), War Letters of Fallen Englishmen, New York, EP Dutton, 1930, p. 296.

16. HARVEY Frederick, poem "A True Tale of the Listening Post", NOAKES Vivien (ed.), Voices of Silence: The Alternative Book of First World War Poetry, Stroud, The History Press, 2006, pp. 90-91.

17. GILLESPIE Alexander, 24 April 1915, Letters from Flanders, London, Smith and Elder, 1916, p. 111.

18. REMARQUE, All Quiet, p. 86.

19. BLUNDEN, Undertones of War, p. 93.

20. тHOMAS R George (ed.), Edward Thomas: Collected Poems, London, Faber \& Faber, 2004, p. 170.

21. See also BULL Michael, "Into the Sounds of War: Imagination, Media and Experience", GRIMSHAW-AAGAARD Mark, WALTHER-HANSEN Mads and KNAKKERgAaRd Martin (eds.) The Oxford Handbook of Sound and Imagination, Oxford, Oxford University Press, 2019, p. 182.

22. FUSSELL, The Great War, p. 235.

23. STERLING Robert, letter to a friend, 18 April 1915, HOUSMAN (ed.), War Letters, p. 263.

\section{ABSTRACTS}

Sound scholars and historians have made much of the noise of warfare. In the trenches of the Western Front, however, there was more to hear than the unprecedented noise of shelling, and the cultivation of listening for danger and for safety brought other sounds to the ear that could offer relief from the intensity of the conflict. Often these were the sounds of nature: birdsong, trees and the stillness of the heavens above the battlefields. Soldiers' writing (letters, diaries, memoirs and poems) reveals a deep engagement with these sounds as part of an effort to make sense of the fearsome environment in which men were contained. Birdsong in particular gave harmony and rhythm to a fractured and unpredictable sound-world. It made coherent, if only for a moment, the possibility of continuity and survival. High above the trenches, it was the cascading song of the lark that cleansed the air and drew eyes further upwards to an imaginative cosmic escape.

Les spécialistes du son et les historien.nes ont beaucoup exploré le bruit de la guerre. Néanmoins, dans les tranchées du front de l'Ouest, il y avait plus à entendre que le bruit inédit des bombardements. Une culture de l'écoute orientée vers le danger et la sécurité n'excluait pas d'autres sons qui pouvaient offrir un soulagement face à l'intensité du conflit. Ces sons 
provenaient souvent de la nature : le chant des oiseaux, les arbres et le calme du ciel au-dessus des champs de bataille. Les écrits des soldats (lettres, journaux intimes, mémoires et poèmes) révèlent un intérêt profond pour ces sons en tant qu'ils participaient d'un effort pour donner un sens à l'environnement redoutable au sein duquel les hommes étaient confinés. Le chant des oiseaux, en particulier, donnait de l'harmonie et du rythme à un monde sonore fracturé et imprévisible. Il donnait une cohérence, ne serait-ce que pour un instant, à la possibilité d'une continuité et d'une survie. Au-dessus des tranchées, c'étaient les jaillissements du chant de l'alouette qui purifiaient l'air et élevaient le regard vers une évasion cosmique imaginée.

\section{INDEX}

Mots-clés: Première Guerre mondiale, front de l'Ouest, tranchées, nature, son, écoute, rythme, chant d'oiseaux, bruit, silence

Keywords: First World War, Western Front, trenches, nature, sound, listening, rhythm, birdsong, noise, silence

\section{AUTHOR}

\section{MICHAEL GUIDA}

Michael Guida is a cultural historian with a particular interest in the place of nature in ideas of British modernity. He is a research associate and tutor in Media \& Cultural Studies at the University of Sussex, UK, and is completing a book for OUP called Listening to British Nature: Wartime, Radio and Modern Life, 1914-45. His recent publications include a book chapter about Ludwig Koch's birdsong broadcasts during the Second World War in the monograph Being Modern: The Cultural Impact of Science in the Early Twentieth Century (UCL Press, 2018), and another about birdsong and emotions in The Routledge Companion to Animal-Human History (2018). 